
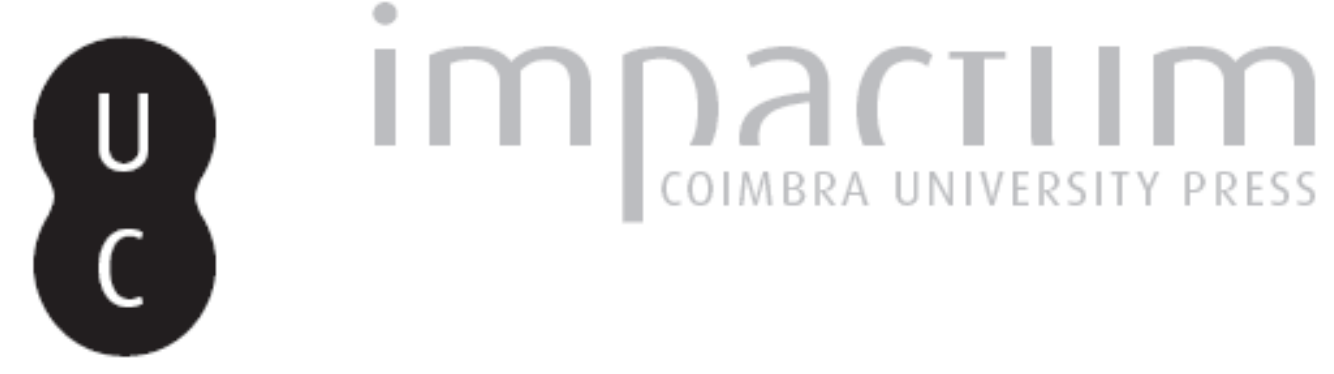

\title{
Encontros, des-encontros e re-encontros entre o Ocidente e o Oriente: notas sobre o Budismo e o Neo-Budismo Filosófico europeu e português
}

Autor(es): Ribeiro, Henrique Jales

Publicado por: Faculdade de Letras da Universidade de Coimbra

URL persistente:

URI:http://hdl.handle.net/10316.2/39974

DOI:

DOI:https://doi.org/10.14195/0870-4112_2_7

Accessed : $\quad$ 26-Apr-2023 11:40:43

A navegação consulta e descarregamento dos títulos inseridos nas Bibliotecas Digitais UC Digitalis, UC Pombalina e UC Impactum, pressupõem a aceitação plena e sem reservas dos Termos e Condições de Uso destas Bibliotecas Digitais, disponíveis em https://digitalis.uc.pt/pt-pt/termos.

Conforme exposto nos referidos Termos e Condições de Uso, o descarregamento de títulos de acesso restrito requer uma licença válida de autorização devendo o utilizador aceder ao(s) documento(s) a partir de um endereço de IP da instituição detentora da supramencionada licença.

Ao utilizador é apenas permitido o descarregamento para uso pessoal, pelo que o emprego do(s) título(s) descarregado(s) para outro fim, designadamente comercial, carece de autorização do respetivo autor ou editor da obra.

Na medida em que todas as obras da UC Digitalis se encontram protegidas pelo Código do Direito de Autor e Direitos Conexos e demais legislação aplicável, toda a cópia, parcial ou total, deste documento, nos casos em que é legalmente admitida, deverá conter ou fazer-se acompanhar por este aviso.

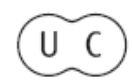


REVISTA DA FACULDADE DE LETRAS U N I VERS I A D E D E C O I M B RA 


\title{
Encontros, Des-encontros e Re-encontros entre O Ocidente e Oriente:

\author{
Notas sobreo Budismo e o Neo-Budismo \\ Filosófico Europeu e Português
}

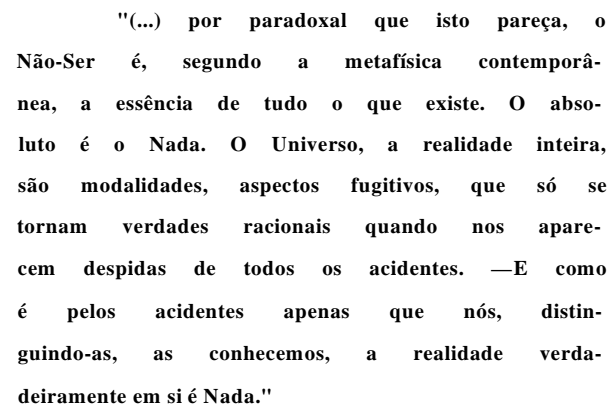

Oliveira Martins.

\begin{abstract}
:
In this paper the author discusses the encounter between Occident and Orient in European philosophy in the second-half of the nineteenth-century and, especially, its philosophical meaning in that context. He takes as case studies Ch. Renouvier and M. Guyau, in France, E. von Hartmann, in Germany, and A. Quental, O. Martins and L. Coimbra in Portugal. He shows that we can find a sort of Buddhism disseminated in several European philosophical circles at that time, mainly in German monism and pantheism, and in French spiritualism and neo criticism. This came about as a result of the interest in using philosophy to explain the relationship between the Individual and the Whole. He suggests that European philosophy didn't actually have a clear view on what Buddhism means and what its implications are. Furthermore, he holds that, long before our contemporary globalization -whose relevance until now can be reduced only to technological aspects- there was $a$ philosophical and religious globalization, at that time, con cerning both occidental (Christianity) and oriental religions (Brahmanism and Buddhism), and that Buddhism was at its core.
\end{abstract}


Henrique Jales Ribeiro

\section{Nota introdutória \\ Globalização filosófica: o encontro das religiões na segunda metade do século XIX}

Numa época em que a problemática (tecnológica e científica, política, social, religiosa e cultural) da globalização está, aparentemente, apenas pela pri meira vez na ordem do dia, e, com ela, a questão das complexas relações entre o Ocidente e o Oriente, tendemos a esquecer que ambas tiveram os seus anteceden tes mais ou menos remotos na história do pensamento europeu e ocidental de maneira geral, e que os mesmos possuíram, neste ou naquele caso, uma significa ção claramente filosófica, com a qual podemos, hoje em dia, aprender, em ordem a re-pensar, constructivamente e de uma só vez, tanto uma como outra. Não é descipiendo falar, deste ponto de vista, de uma problemática filosófico-religiosa da globalização na ocasião da profunda crise que abalou um tal pensamento, na segunda metade do século XIX, com o impacto das filosofias da evolução sobre as concepções religiosas e o que já se tornou comum denominar, em relação à época, como a "descristianização progressiva" do Ocidente. Esta, entre outras implica ções, levantou o problema das relações entre o mundo cristão e o Oriente islâ mico, bramânico e budista, que foi um dos temas fulcrais do primeiro fórum internacional na matéria, -o Parlamento das religiões reunido em Chicago em 1894. E está na base, no que à filosofia em particular diz respeito, da tentativa, por parte de certas correntes filosóficas europeias, de re-pensar, no seu próprio qua dro, alguns dos temas fundamentais das religiões orientais, como o budismo. Deste ponto de vista, Charles Renouvier, em 1897, —isto é, três anos depois da realização do aludido Parlamento--, sugerirá expressamente essa globalização filosófica a que nos referimos, apelando para a teoria da evolução de Spencer:

Hoje em dia entrevemos a unidade de comunicações e de relações envolvendo o globo no seu conjunto e a formação bem possível de um sincretismo novo em que se uniriam (...) os métodos racionais e científicos da tradição euro peia com as crenças fundamentais do Oriente bramânico e búdico, sob o princípio filosófico comum da evolução de uma natureza saída do Incognoscível. ${ }^{1}$

Fazendo o balanço do "pessimismo do pensamento moderno" na segunda metade do século XIX, comentava esse filósofo francês que, sendo certo o fim do cristianismo tradicional e que as "religiões do futuro" alternativas já anunciadas e por anunciar — contra as melhores

${ }^{\wedge}$ Ch. Renouvier, Philosophie analytique de l'histoire. Tome quatrième: Les idées, les religions, les systèmes (Paris, Ernest Leroux 1897) 743-744, s. n..

\section{Faculdade de Letras | Universidade de Coimbra}


expectativas dos seus proponentes, como Hartmann- não deram qual quer verdadeiro fruto para além do ateísmo, talvez porque "um movi mento religioso importante só poderia verificar-se numa época mais avançada de decadência" — como será o caso da da altura--, este, a ocor rer, "não interessará apenas à Europa, este 'mundo cristão' cujo isola mento moral do mundo oriental parece estar a chegar ao fim"* ${ }^{2}$, mas a Ocidente e Oriente no seu conjunto. Um índice evidente da possibilidade de um tal encontro entre as duas civilizações, cujas implicações estarão longe de se reduzir ao âmbito filosófico e religioso, é que, na sequência de Darwin e da filosofia da evolução, o pensamento europeu se afastou claramente de várias partes essenciais do cristianismo, - tais como as crenças na criação do mundo, na existência de um paraíso celeste e numa liberdade originária que o pecado revogaria por decreto divino--, apro ximando-se, por outro lado, de outras não menos fundamentais, caracte rísticas do bramanismo e, sobretudo, do budismo orientais. Metafisicamente considerada, a filosofia da evolução estará pois no cerne, pela primeira vez na história do pensamento mundial, da eventualidade de um tal encontro civilizacional.

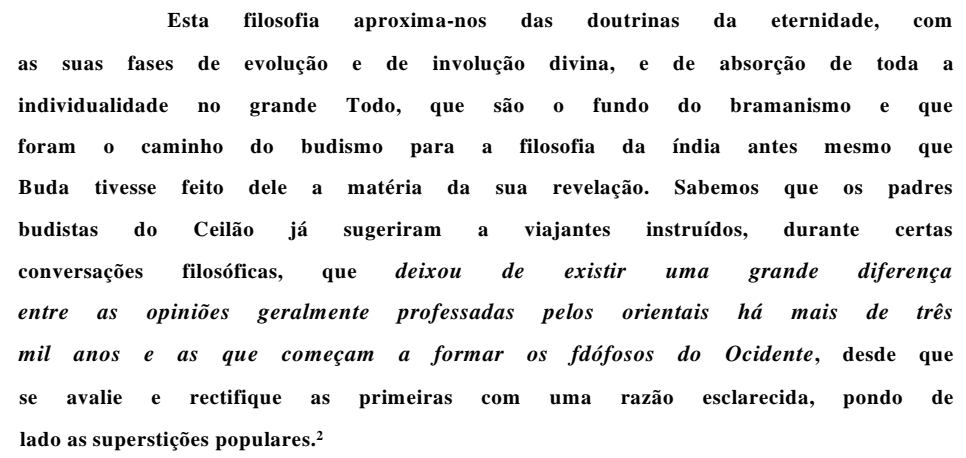

Em que sentido é que a filosofia da evolução pôde aparecer, por intermédio do budismo, como matriz do encontro entre o Oriente e o Ocidente? As diferentes filosofias da segunda metade do século XIX, depois das grandes sínteses de Hegel e de Comte e reflectindo justamente o impacto das teorias da evolução de fundo darwinista, estão geralmente de acordo que a natureza e o homem são constituídos por uma hierarquia

${ }^{2}$ Idem, ibidem, 742.

${ }^{2}$ Idem, ibidem, 742-743, s. ...

Faculdade de Letras Universidade de Coimbra 
de graus ontológicos, os quais correspondem basicamente, caso a caso, à série de planos das diferentes ciências (do mundo ao homem, à sociedade e ao Espírito), e dos quais o homem e a sociedade eles mesmos no seu conjunto são a expressão final ou derradeira do ponto de vista da metafí sica, da ética, da religião e da política. A filosofia, fechando os graus ou planos e a hierarquia no seu conjunto deste ou daquele modo organizador, integrará superadoramente os resultados respectivos. Assim compreen dida, a ideia de hierarquia —que alguns retomam eclécticamente da Enci clopédia do alemão, do Curso de filosofia positiva do francês e da filosofia da evolução de maneira geral-pressupõe que o homem é a pró pria natureza interiorizada, em-si e para-si, desde um estrato mecânico em que consistem as determinações mais inferiores do real à acção livre pela qual se manifesta a sua consciência reflexiva como ser em sociedade. Do ponto de vista da filosofia da evolução, em particular, o desenvolvimento da hierarquia coincidirá com o da natureza e o da história em geral, ou seja, com o desenvolvimento do seu próprio princípio interno dinamiza dor, seja ele o "Espírito" ou qualquer outra das suas versões (o "Incognoscível" de Spencer, o "Inconsciente" de Hartmann, etc.). Evolução que é também involução, na justa medida em que o homem, no cume da hierar quia, há-de poder de algum modo, regressivamente, reapreender a expli citação gradual desse princípio, enquanto ele é imanente à natureza e à história, do fim para o começo, sejam estes quais forem. E, por outro lado, uma vez apeado o mito cristão da criação do mundo, ao encontro das doutrinas orientais da eternidade do mundo, evolução e involução que não são apenas próprias do nosso mundo mas de uma inifinidade de mun dos possíveis.

As implicações metafísico-religiosas desta concepção eram enormes, porque a filosofia da evolução, ao mesmo tempo que abria um fosso claro entre a ciência e os dogmas basilares da religião (criação, queda, providência e redenção), não deixava de naturalizar e secularizar o Deus do cristianismo sob esta ou aquela veste filosófica peculiar. A questão fundamental que se colocava e estava na base das divergências inter scholia, consistia, por um lado, em saber como interpretar esse prin cípio motor e explicador da relação entre os diferentes graus da hierarquia da natureza e do homem (de onde diferentes versões de naturalismo, materialismo, idealismo e espiritualismo), e, por outro, em saber se, longe de lhes ser transcendente como no cristianismo, ele se reduz ou é ima nente ou não à natureza e ao homem ele mesmo (de onde as várias moda lidades de teísmo, monismo e panteísmo). É esta representação de um homem que está no cume da hierarquia, um homem na sua relação com 
uma Unidade ou um Todo à qual pertence ou terá pertencido de algum modo originariamente, que agora, na perspectiva dos resultados da filo sofia da evolução, se associa ao budismo $e$ às religiões orientais de maneira geral. Veremos que é o caso do budismo e do neo-budismo filosófico europeu e do português dos anos sessenta do século XIX em diante.

A decadência moral europeia e ocidental de maneira geral, que está na base das diferentes versões filosóficas do pessimismo e do nii lismo na segunda metade do século XIX (de Schopenhauer a Hartmann, de Nietszche a Spencer), algumas das quais, como se sabe, se reclamam do budismo, só tinha paralelo, para Renouvier (e mais tarde, de um outro ponto de vista, Oliveira Martins), com aquela que oferecia a civilização helénica no seu próprio tempo antes da assimilação romana, ou, mais explicitamente, com a que apresentava a antiguidade greco-romana antes das invasões góticas (ou "bárbaras", como na época ainda se dizia), com a reserva essencial de que, agora, será inteiramente possível um verdadeiro sincretismo civilizacional entre o Ocidente e o Oriente no seu conjunto (incluindo neste não apenas a Pérsia, como aconteceu com a Grécia clás sica, mas a índia e a China), que harmonize, sob um princípio filosófico e ecuménico comum que tem como cerne justamente a ideia de evolução da natureza, os métodos racionais e científicos da tradição europeia com as crenças fundamentais do Oriente bramânico e búdico. ${ }^{4}$ É uma tal conclu são que o próprio Parlamento das religiões sugeriu através de diversas e autorizadas vozes, declarando ao mundo que todos os cultos religiosos são "as manifestações históricas de uma religião una e eterna sob a diver sidade das formas."5 Esse sincretismo, recuperando o que de melhor haverá nas várias formas da filosofia do absoluto e das doutrinas infinitistas, de que o cristianismo é um exemplo, pode constituir uma alterna tiva vitoriosa ao pessimimo europeu e ocidental característico de uma "sociedade velha e fatigada", restaurando, no que à metafísica diz respeito em particular, o optimismo que imbuía a filosofia da evolução no seu início. ${ }^{6}$ Ora, considerando que, para Renouvier, o budismo reunirá, filosoficamente falando, o que de melhor haverá no bramanismo, é ele, uma vez devidamente reformulado ou reorientado na perspectiva da sua síncrese com um cristianismo ele mesmo transformado, que deve consti tuir, quer para o "sentimento religioso" propriamente dito quer para a

${ }^{4}$ Idem, ibidem, 743.

${ }_{5}^{5}$ Idem, ibidem, 744.

'Idem, ibidem, 745 . 
"metafísica mais consequente", a matriz do encontro civilizacional entre Ocidente e Oriente. ${ }^{7}$ Pondo de parte o "enigma" europeu constituído por esse sincretismo civilizacional que é a Rússia, é isso que já podemos deduzir, sem qualquer admiração, do sucesso filosófico da introdução do budismo na Europa, especialmente na Alemanha. ${ }^{8}$ Seja como for, de uma tal matriz importa expurgar aquele mesmo pessimismo negador do desejo, da individualidade pessoal, do fim divino das coisas e, em última análise, da vida na sua essência, que Schopenhauer elevou a ideário filosófico tomando o budismo do dia ou oficial como verdade suprema, e que, na verdade, sob outras vestes, podemos encontrar ainda a Ocidente quer na filosofia da evolução quer na própria teologia cristã. ${ }^{9}$ Metafisicamente reinterpretada a ideia essencial de uma fusão ou absorção do individuo no seio do Todo, no sentido em que se venha a admitir que a pessoa é uma realidade e que a vontade humana é criadora, que tanto a criação como a eternidade do mundo - qualquer que seja a forma que venham a assumir na perspectivada "transformação do budismo"- são acontecimentos de ordem divina, e que a queda, a dor, o mal ou o pecado não são apenas vias de passagem a transcender, a teosofia budista pode constituir a verdadeira "religião do futuro", reiteradamente prometida, sem sucesso, pelos filóso fos do pessimismo e do niilismo mas agora auspiciosamente augurada, em novos termos, pelo Parlamento das religiões.

A questão essencial levantada por Renouvier, quanto às impli cações da filosofia da evolução e da problemática das religiões orientais para o pensamento europeu, é, pois, em síntese e grosso modo falando, a de saber como é possível pensar a natureza da relação do homem com o Todo que é suposto constituir o universo, e é a uma tal questão, dada a conhecida apropriação - na sequência das grandes sínteses de Comte e de Hegel —da problemática religiosa pelo pensamento filosófico propria mente dito na segunda metade do século XIX, que compete à filosofia enquanto tal responder, depois do fracasso das diferentes soluções natu ralistas e materialistas da filosofia da evolução ${ }^{10}$ e do pessimismo e nii lismo característicos da metafísica europeia e ocidental de maneira geral. $\mathrm{Na}$ verdade, é justamente isso que farão, especialmente em França, para além do criticismo do próprio Renouvier, o espiritualismo e outras escolas

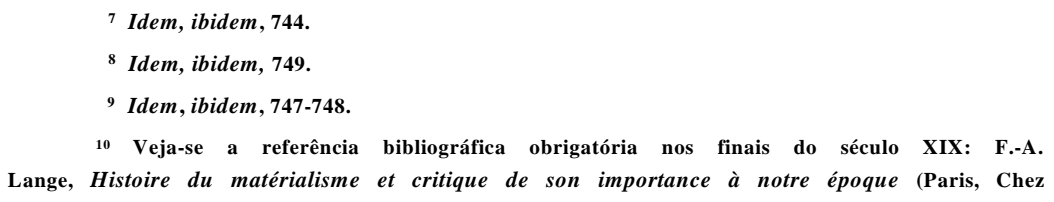


filosóficas que tiveram um impacto notável na filosofia em Portugal, da época, como é o caso da de Antero e, um quarto de século depois, da de Leonardo Coimbra. Nestas, como naquelas, encontramos um retorno explícito a esse tema budista fundamental que Renouvier tinha elegido e que marca o encontro filosófico entre o Ocidente e o Oriente no seu con junto. Encontro deduzido, uma vez que o budismo, como já se sugeriu, não é ponto de partida mas algo filosoficamente inferido. ${ }^{11}$

\section{A "religião do futuro" de Hartmann e a "irreligião do futuro" de Guyau: sobre a recepção ocidental do budismo}

Sobre o budismo, cerca de um quarto de século antes da grande síntese de Renouvier, tinha E. von Hartmann dito em A religião do futuro, relançando a problemática filósofico-religiosa do impacto do mesmo no Ocidente depois de Schopenhauer e de Nietzsche, que ele é "o único sis tema em que o pessimismo serve expressamente para fundar a morali dade."12 Sendo certo que a um tal sistema falta uma moral (optimista) da redenção, de que o cristianismo é exemplo à sua maneira, e que, portanto, importa de algum modo transformar ou renovar o budismo ortodoxo na perspectiva de uma síntese entre as duas religiões, o pessimismo não só não é um mal em si mesmo como, bem compreendido, é uma realidade insofismável (para a época) e uma "disposição essencial da humanidade", propedeuticamente necessária como fundamento ético da possibilidade de qualquer religião e da metafísica de maneira geral. ${ }^{13}$ Temperar e reabilitar o pessimismo, entretanto, não é a única alteração essencial a fazer, filoso ficamente falando, à teoria do autor de $\boldsymbol{O}$ mundo como vontade $\boldsymbol{e}$ como representação e à doutrina do próprio Buda: com ela, vai uma rejeição do "ilusionismo" deste último e do shopenhaueriano, herdado de Kant, para os quais o mundo não seria mais do que uma aparência subjectiva da essência da realidade, e, consequentemente, do "quietismo apático" e da

11 Uma das consequências fundamentais deste encontro entre Ocidente e Oriente e da globalização filosófica que ele anunciava, na segunda metade do século XIX, é a proliferação, a partir dessa altura, estudos sobre a história das religiões orientais — já não apenas a respeito da Pérsia, mas do Oriente no seu conjunto--, e de estudos propriamente comparativos entre estas e as ocidentais, cuja importância, em alguns casos, não é apenas histórica ou historiográfica mas essencialmente filosófica. Teremos ocasião de o constatar, no caso português, a respeito da Oliveira Martins.

12 E. von Hartmann, La religion de l'avenir (Paris, G. Baillière 1877) 169-170.

13 Idem, ibidem, 169-170, 138 e ss.. 
"indolência absoluta" de uma redução nirvânica Analizadora, ascética e mística, que se é conduzido a entronizar como ideais da filosofia, da moral e da religião. O que significa, por outras palavras, retornar e aderir, neste ponto, à ideia judaico-maometana-cristã da realidade e consistência ontológicas do tempo, que foi, entre outros e contra a estagnação cientí fica e cultural do Ocidente, um factor do progresso do Ocidente no seu conjunto. ${ }^{14}$ Uma vez rompidos os ilusionismos budista e kantiano, e, reencontrando o Oriente de forma diferente, retomada a ideia da unidade essencial entre a essência do homem e a da própria realidade, quer dizer, reposta no seu devido lugar a verdadeira condição de possibilidade da acção moral e religiosa, deixa de fazer sentido a problemática teológica do teísmo e da criação do mundo em particular, tal como esta foi conce bida tradicionalmente no Ocidente, e é um monismo espiritualista, panteísta e imanentista, síntese dos optimismos e pessimismos possíveis, que se apresenta como a solução final integradora:

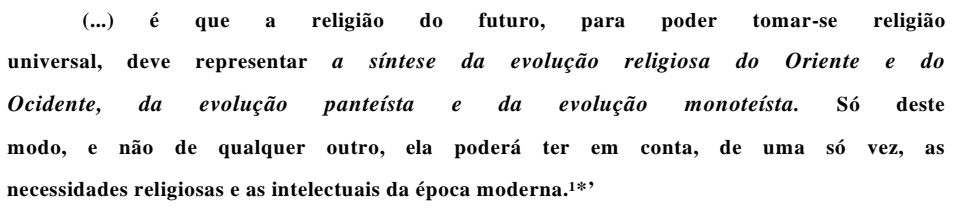

Eis, resumidamente, as linhas gerais do "budismo degradado" (na interpretação de Renouvier) ${ }^{16}$ de Hartmann. A suposta "degradação", que tem em vista ironicamente as divergências entre o filósofo e o seu mestre Schopenhauer, consistirá no facto de que a nova "religião do futuro" não é imune, bem pelo contrário, à influência cristã, enquanto a mesma pode, neste ou naquele aspecto, dar significação moral e filosófica a um budismo ortodoxo. Aqui e ali lembra Hartmann, neste sentido, que, se é verdade que existe uma contradição insanável entre a dogmática do cristianismo, por um lado, e a ciência e a cultura, por outro, o sentimento religioso responde às necessidades metafísicas mais profundas do homem na sua relação com o mundo; ${ }^{17}$ que uma tal relação passa, de forma essencial, pelo mistério, e, contra as pretensões dessa dogmática, que este não é completamente decifrável e/ou racionalizável, abrindo "um mundo

14 Idem, ibidem, 163.

1 ^ Idem, ibidem, 139-140, s. $\boldsymbol{\eta}$..

$\wedge$ Ch. Renouvier, op. cit., 420.

${ }^{17}$ E. von Hartmann, op. cit., 102-103. 
infinito à pessoa que o medita e aos pressentimentos do coração", 18 como a sua filosofia do Inconsciente mostra; e, finalmente, que o amor e a cari dade, que nas apologéticas cristãs só justificam, de facto, pseudo-morais heterónimas e individualistas, só são possíveis numa ética e metafísica panteístas, que elevam ambos à sua dignidade própria. ${ }^{19}$ Por isso, não estranhará que estas últimas, na religião do futuro e em contraste com a cristã, estejam ao serviço de um culto individual e interior, quer dizer, da profundidade da emoção e da satisfação religiosas nas suas expressões mais verdadeiras. ${ }^{20}$ Do que se trata para Hartmann, no fundo, é de uma reabilitação tanto do budismo como do cristianismo, ou, se se preferir, de uma fundação metafísica da religião globalmente considerada, do Oci dente ao Oriente, que, quanto às duas partes, visa harmonizar a mesma com a ciência, a filosofia e a cultura no seu conjunto, numa época em que, sobretudo quanto à primeira, a desintegração niilista das consciências morais e religiosas dilacerava as sociedades. Se o acicate de um tal desi derato é, na maior parte, ocidental, o seu horizonte, por sua vez, é predo minantemente oriental. Como ele dirá, o homem contemporâneo deve confessar francamente que o edifício religioso, esburacado e corroído em todos os sentidos pelo espírito crítico da nossa época, não poderia mais ser mantido. Esperemos que, uma vez bem constatadas uma tal insufi ciência e a angústia acutilante associada, as mesmas se tomem o estímulo mais enérgico para a investigação e descoberta de ideias religiosas de uma outra proveniência [Oriente], que estejam aptas a substituir e mesmo a ultrapassar as conhecidas." 21

Do que foi dito e do que se sugeriu, podemos concluir estarmos longe, nesta transformação do budismo como nova religião do futuro, da redução simplista deste à doutrina, que um Oliveira Martins em Portugal defenderá, segundo a qual ele consistiria na absorção nadifícadora do individuo pelo Todo, a qual, partindo de um mal e dor mundanas a trans cender, constituiria o ponto de chegada de um movimento redentor, ascé tico e místico, feito a-socialmente se não mesmo anti-socialmente. Nem uma tal redução admissível seria, uma vez que a essência do homem, para o Hartmann de A filosofia do inconsciente, exprime a essência do mundo ela mesma (o Inconsciente precisamente) no grau mais alto do seu desen

\footnotetext{
18 Idem, ibidem, 107.

19 Idem, ibidem, 122-123;

$20 \quad$ Idem, ibidem, 172-173.

21 Idem, ibidem, 13.
}

Faculdade de Letras i Universidade de Coimbra 


\section{Henrique Jales Ribeiro}

volvimento. $^{22}$ Por isso, reformular o budismo significa aqui também, se não fundamentalmente, —sob pena de transfigurá-lo ou caricaturá-lo--, reformular a experiência, só de forma superficial por ele patenteada, da união entre o homem $\boldsymbol{e}$ o Todo. Este é, de facto, um aspecto decisivo da diferença entre o budismo de Hartmann e o tradicional, de Hegel a Scho penhauer, incluindo aí a versão crítica, contestária, apresentada por Nietzsche. ${ }^{23}$ Pode uma tal experiência, de algum modo, ser uma experiên cia viva, afectiva e sentimentalmente falando, e, por outro lado, constituir um momento de partilha, no próprio interior de cada indivíduo, do Todo com os outros, aqui em baixo, onde sofremos, e não num qualquer suce dâneo da eternidade celestial? Se o budismo não é uma simples panaceia, será que se pode ser budista, apesar de tudo, transformando-o a ponto de não o reconhecermos nem nos re-conhecermos nele? Eis a via, neobudista para todos os efeitos, para a qual se inclina a nova religião do futuro do filósofo alemão, que, sob outras vestes, vai ser o caminho já não dos encontros com o budismo, mas, à maneira hegeliana da aufhebung, dos des-encontros e re-encontros com ele. ${ }^{24}$

É o caso do des-encontro versus re-encontro de $\boldsymbol{\Lambda}$ irreligião do futuro, de Guyau, publicada no dealbar do século XX. ${ }^{25}$ Compreende-se que, tal como o conceito de budismo, o de religião, em certa medida, tenha deixado de fazer sentido. É justamente isso que o filósofo francês, do seu próprio ponto de vista, recorda a Hartmann, propondo o abandono do último e consagrado conceito. ${ }^{26}$ "Irreligião", entretanto, não significa a-religião nem, muito menos, anti-religião, porque a religião, também para Guyau, sempre tendo uma base positiva, sociológicamente falando, e independentemente desta ou daquela tradução dogmática, é uma "explica ção física, metafísica e moral" do mundo e da relação do homem com o

22 Veja-se E. von Hartmann, Philosophie de l'inconscient (Paris, F. Alcan 1877, 2 vol.s); e idem, Le darwinisme. Ce qu'il y a de vrai et de faux dans cette théorie (Paris, F. Alcan 1894).

23 Sobre a história do budismo, de Hegel em diante, veja-se Roger-Pol Droit, Le culte du néant: les philosophes et le Boudha (Paris, Seuil 1997) 91 e ss. Sobre o budismo de Nietzsche, ver M. Conche, Nietzsche et le boudhisme (Fougères, Encre Marine 1977).

24 A via neo-budista passa pela contestação e rejeição do budismo na sua versão ortodoxa, como se dela nada restasse ou ficasse de pé. Esta negação é, na realidade, uma de negação: sob os escombros dessa versão, uma reinterpretação inovadora do budismo, jamais claramente assumida ou confessada, se apresenta.

${ }^{23}$ M. Guyau, L'irréligion de l'avenir. Étude sociologique (Paris, Félix Alcan 1902).

26 Idem, ibidem, XII. 
mundo. ${ }^{27}$ Mas, mais decisivamente para o autor de $\boldsymbol{A}$ irreligião do futuro, na sequência de Nietzsche, já não se justificava, na época, a distinção entre religião e metafísica, ou entre religião, metafísica e moral, os ele mentos característicos de qualquer um desses domínios, em particular, uma racionalidade amputada do respectivo enraizamento na essência do homem, tendo-se tornado caducos. $^{28}$ De onde se segue que deixa igual mente de ser actual e pertinente o objectivo de uma unificação final das religiões sob a égide do budismo, porque, entre outras razões, qualquer uma delas mostra ser impotente para assimilar as outras. ${ }^{29}$ Em contraste, do que se trata agora, desde logo, é de converter os diferentes dogmas religiosos "num certo número de hipóteses definidas entre as quais cada indivíduo fará uma escolha progressivamente mais razoável", para, final mente, vir a reduzi-las à sua dimensão essencialmente moral. ${ }^{30}$ Por esta via, que tem como directriz uma filosofia do indivíduo onde a metafísica do Assim falava Zaratustra encontra algum eco, vai a problemática do budismo ser criticada e repensada. Em oposição ao panteísmo de Hart mann ou ao de Spencer, que mais não são do que formas de divinizar o Infinito, à maneira bramânica e/ou budista, personalizando-o e atribuindolhe uma misteriosa unidade de essência, ${ }^{31}$ é na natureza do homem, quer dizer aqui, de cada indivíduo ou do Indivíduo numericamente conside rado, nesse sentimento radical e afectivamente determinado de aprofun damento, interiorização-expansão da sua personalidade em toda a sua plenitude - pelo qual ele se reapreende na sua essência mais íntima e reapreende originariamente o próprio Todo ou a "vida universal"—, ${ }^{32}$ que deve procurar-se o fundamento -um fundamento, caracteristicamente optimista perante o pessimismo reinante, da possibilidade do amor e da comunhão universais sempre prometidas mas nunca alcançadas pelas diferentes religiões - da irreligião do futuro na perspectiva que foi esbo çada. $^{33}$ Era o que Guyau tinha já defendido, independentemente da problemática filosófico-religiosa, em A moral sem obrigação nem sanção e noutros trabalhos, que terão um influência marcante em Leonardo Coimbra e que, a seu modo, apresentam algumas das ideias de A.

27 Idem, ibidem, II.

28 Idem, ibidem, XIV.

29 Idem, ibidem, 17 e ss, e 299-300.

30 Idem, ibidem, 373.

31 Idem, ibidem, 15 e 31.

32 Idem, ibidem, 314, 327, 337, etc..

33 Idem, ibidem, 337. 


\section{Henrique Jales Ribeiro}

Fouillé. $^{34}$ Pode um tal sentimento ou uma tal des-razão, de maneira mais marcante do que acontece com a alegria de Nietzsche, ser expressão de uma nova racionalidade e especulação nos tempos modernos? Guyau defende e reitera uma tal tese no seu livro. ${ }^{35}$ É natural, em consequência, que, tendo em vista a representação oficial do budismo ortodoxo na segunda metade do século XIX —aquela que o identifica à redução ascé tica e mística do indivíduo ao Nada ou ao Não-Ser--, ele a contraponha à sua própria experiência metafísico-religiosa do sentimento referido, salientando as enormes diferenças e vantagens desta última. A diferença crucial, como se sugeriu, é que a experiência do nirvana será totalmente vazia de conteúdo, não só afectivo e moral em sentido amplo, mas tam bém metafísico ou intelectual. Daí, num primeiro momento, o des-encontro com o budismo:

(...) É a concepção do nirvana. Cortar todos os laços que nos ligam ao mundo exterior, suprimir todos os sinais recentes de novos desejos e crer que, auto-limitando-se assim, nos entregamos a algo diferente; praticar uma espécie de circuncisão interior completa, retornar a si mesmo e crer que se penetra então na intimidade do Todo (...); abrir no fundo de si um abismo, sentindo nele a vertigem do vazio, mas crendo, contudo, que este vazio é a plenitude suprema, (...) foi sempre uma das maiores tentações do homem, pelas mesmas razões que se caminha desde muito longe ao longo de grandes precipícios com nenhum outro objectivo se não o de neles se inclinar e experimentar uma atracção indefinível. A noção panteísta ou monista do nirvana escapa a qualquer crítica, precisamente porque é uma realidade vazia de todo o conteúdo preciso. ${ }^{36}$

Note-se, mais uma vez, que, se é verdade que esta concepção do budismo se adequa bem à de Schopenhauer, estamos muito longe do budismo transformado de Hartmann, que não se eximiu, por diversas vezes, de criticar e afrontar abertamente a doutrina do próprio Buda, em particular "O seu erro de que o mundo não é se não a aparência de um nada (...), que faz do universo um sonho e crê tão pouco numa reali-

34 Veja-se idem, Esquisse d'une morale sans obligation ni sanction (Paris, F. Alcan 1896). De A. Fouillé, sobretudo, L'évolutionisme des idées-forces (Paris, Félix Alcan 1890). Sobre a relação entre Fouillé e Guyau, A. Fouillé, "La doctrine de la vie chez Guyau, son unité et sa porté", in Revue de Métaphysique et de Morale (Paris, Armand Colin 1906) 514-544 .

35 M. Guyau, L'irréligion de l'avenir, especialmente, 314-315.

36 Idem, ibidem, 416-417.

\section{Faculdade de Letras | Universidade de Coimbra}


dade qualquer que não concebe mesmo a necessidade lógica de uma rea lidade subjacente à aparência' $\ddot{i}^{I}$ E, depois, que o arrazoado anti-budista do autor, no trecho citado, contrasta claramente com inúmeras outras refe rências históricas e filosóficas favoráveis ao budismo, sobretudo quando ele é comparado com o cristianismo. ${ }^{38}$ Estaremos autorizados mesmo assim, depois do que fica dito, a falar de uma noção do nirvana não panteísta mas naturalista e, em certa medida, monista (tanto quanto se pode dizer, como reinvindica Guyau, que uma filosofia centrada sobre o Indi víduo e sobre a ideia de que este exprime a unidade substancial do Todo, é monista), ${ }^{39}$ que, superando de um só vez o teísmo (característico do cristianismo) e o panteísmo (inerente ao budismo), corresponderá à expe riência idealizada pelo próprio Guyau e em comparação com a qual esta, particularmente em A irreligião do futuro, terá sido concebida por analo gia? Depois do des-encontro com o budismo, que mais acima exemplifi cámos, haverá lugar, dialecticamente, para um re-encontro?

Logo à partida, a reinterpretação de Guyau —na sequência de Spencer e, sobretudo, de Hartmann— da aplicação da filosofia da evolu ção à teoria das religiões e da cosmologia que daí se segue —que restaura a ideia essencial de um Todo não criado, uno e imanente, dado na essên cia mais profunda de cada Indivíduo, que evolui na natureza em geral e involuíu na experiência-síntese, metafísico-religiosa, da sua reapreensão--, confere uma significação tendencialmente panteísta ao seu natura lismo monista, cuja origem é por demais evidente: "Não é o ser que surge do nada, é o nada que é um simples aspecto do ser, ou melhor, uma ilusão do pensamento. Por isso, se deverá renunciar à ideia de criação, que será substituída pela de variação e de evolução. Os diversos mundos não são mais do que eternas variantes do mesmo tema. O tat twam asi dos Hindus tende a tornar-se uma verdade científica. A unidade substancial do mundo e a solidariedade de todos os seres chegará a ter, sem dúvida, uma demostração cada vez mais evidente."40 Apeado o mito cristão da criação, ao encontro das religiões orientais interpretadas à luz da filosofia da evo lução, toma-se possível conceber a existência de outros mundos, para além do nosso, e a globalização fdosófica e cosmológica (destino dos mundos) de Renouvier torna-se um facto. $O$ que resta, filosoficamente falando, da criação divina numa teologia cristã que já foi despojada dos

\footnotetext{
${ }^{3 \wedge}$ E. von Hartmann, La religion de l'avenir, 150-151.

${ }^{38}$ Cf. M. Guyau, op. cit., 346-347.

${ }^{39}$ Cf. idem, ibidem, 438 e ss..

${ }^{40}$ Idem, ibidem, 379.
}

Faculdade de Letras i Universidade de Coimbra 
dogmas do pecado, da providência e da redenção, mais não é do que a ideia de uma acção espontânea e essencial que caracterizará a natureza de cada Indivíduo e da vida de maneira geral (o Todo), e que está na base da própria experiência-síntese, metafísico-religiosa, de Guyau. ${ }^{41}$ Mas, de forma mais decisiva e a despeito de algumas picardias anti-budistas, por um lado e como já se sugeriu, as recorrentes analogias entre cristianismo e budismo, em $\boldsymbol{A}$ irreligião do futuro, parecem apoiar a ideia de que, ape sar de tudo, o ideal hartmanniano de uma síntese das religiões sob a égide do budismo não morreu completamente, e, por outro, a relação entre o Indivíduo e a unidade substancial do mundo, ou o Todo, que passa por um movimento de interiorização-expansão da sua personalidade, é, tal como no budismo, concebida como aprofundamento, passagem do que é tran sitório ao que é permanente e essencial, e, finalmente, ascenção e redu ção a um plano superior, quase-celestial, de embebência mística:

Quando se sobe a um alto promontório para contemplar uma cadeia de montanhas, vê-se, à medida que nos elevamos, surgir e alinhar ao longo do horizonte os cumes brancos da neve; de pé, uns ao lado dos outros, brilhantes sobre os glaciares, mostram-se em silêncio na luz: parece que um imenso esforço levanta estas massas enormes e as puxa para cima, e que a sua imobilidade é aparente; julgamos sentirmo-nos levados por elas até ao zénite. Também os heróis das lendas da índia, quando se fatigaram da vida e da terra, reuniram as suas últimas forças e escalaram (...) as altas montanhas, os Himalaias; estas conduziam-nos ao céu. (...) Que o homem ponha os sentidos ao seu serviço, empregue todos os seus esforços, utilizando os séculos passados como materiais sobre os quais construirá o futuro; trepando a natureza terá trepado ao céu. ${ }^{42}$

Um fiel seguidor do budismo (mas de um budismo actualizado e renovado ao encontro dos "tempos modernos" da segunda metade do século XIX) não diria algo de muito diferente.

\section{0 "budismo filosófico ocidental", na sequência de Hartmann, de Antero de Quental, e a rejeição do Oriente, de Oliveira Martins}

E tendo como perspectiva uma reinterpretação e reformulação da problemática do budismo como a que temos vindo a expor, e que não se confína de modo algum à versão doutrinária, ortodoxa do mesmo, que

4^Idem, ibidem, 391-392.

${ }^{42}$ Idem, ibidem, 430-431.

Faculdade de Letras i Universidade de Coimbra 
poderemos compreender a evolução das ideias budistas no Ocidente no último quartel do século XIX e, em particular, em Portugal, com Antero de Quental e Leonardo Coimbra.

A propósito do budismo, observa o poeta e filósofo açoriano a W. Storck, que o Ocidente, reagindo contra o pessimismo e a decadência, virá a criar em tempos vindouros "o seu [próprio] Budismo, a sua dou trina mística definitiva e, por todos os lados, em melhores condições do que o Oriente."43 Deste ponto de vista, "a obra destes séculos mais próxi mos será não destruir o cristianismo (quero dizer, o espírito cristão, o ponto de vista da transcendência metafísica e moral) mas completá-lo com a ciência da realidade. A religião do futuro, de que nos fala Hart mann, não pode ser outra, e não julgo necessário ir procurar o Budismo, quando nele o que há de melhor se encontra no cristianismo, e com uma forma sentimental mais pura, mais humana,"44 Sugeria, assim, que a "nova religião" do filósofo alemão e, mais geralmente, o encontro entre o Ocidente e o Oriente, não passava por importar e transpor para aquele, simplesmente, o budismo deste, e que, sempre conservando o que haverá de melhor na metafísica, na religião e na moral ocidentais, era possível transformá-las e renová-las no sentido mais profundo e auspicioso do pensamento oriental. Não era necessário, pois, ir para o Oriente e aí pro curar qualquer coisa que o Ocidente já possuía originalmente e à qual tinha chegado pelos seus próprios pés. Não é algo diferente, praticamente na mesma altura e como vimos mais acima, do que dirão os filósofos apologetas da síntese ou sincretismo entre as religiões, pensando, em especial, na filosofia da evolução. Justifica-se, por isso, falar de um "budismo ocidental" em Quental, como Leonardo Coimbra dirá, de forma pertinente, no livro que ao poeta e filósofo açoriano dedicou. ${ }^{45}$

A atitude perante o cristianismo é, sem dúvida, um ponto essencial das divergências a respeito do budismo entre Quental e o autor de $\boldsymbol{A}$ religião do futuro. Sendo verdade que o budismo de Hartmann não é ortodoxo mas reinterpretado na perspectiva metafísica do seu monismo e panteísmo; sendo igualmente pacífico que ele é mesmo, sem hesitações, um crítico e opositor denodado das versões do budismo que encontrou na tradição ocidental; o facto é que se lhe afigurava inteiramente possível a

${ }^{43}$ Antero de Quental, Obras completas, Cartas II, 1881-1891 (Açores, Editorial Comunicação 1989) 839.

44/í/gw, Obras completas, Cartas 1, [1852J-1881 (Açores, Editorial Comunicação 1989) 348-349, s. n..

45 L. Coimbra, O pensamento filosófico de Antero de Quental (Porto, José Pereira daSilva 1921$) 75$. 


\section{Henrique Jales Ribeiro}

sua transformação ou renovação, enquanto que, no que ao cristianismo diz respeito, não via qualquer verdadeira possibilidade de as mesmas se virem a concretizar. Uma vez submetida a religião cristã ao crivo purifi cador da análise histórica e filosófica, e derrubados todos os dogmas que a caracterizam, praticamente nada de proveitoso restaria dela para além de uma moral difusa e inconsequente, que pudesse constituir fundamento da religião do futuro. ${ }^{46}$ Em consequência, o pendor pessimista e niilista do pensamento essencial de Hartmann levava-o a não considerar outra alter nativa que não fosse, na esteira dos resultados fundamentais alcançados pela ciência, pela filosofia e pela cultura modernas, a da própria auto destruição ou auto-dissolução do cristianismo, o que significava, de facto, que não era necessário, por fora dele ou no seu exterior, aniquilá-lo, uma vez que ele mesmo, por dentro, estava a desempenhar uma tal funebre tarefa.

Em que sentido é que a metafísica e a religião ocidentais, para Quental, caminham no mesmo sentido que o budismo oriental? A resposta está, como sugerimos mais acima, na interpretação, no âmbito da filosofia da evolução, da natureza e do homem através da ideia de uma hierarquia de planos ontológicos fundamentais que os constituiriam e que corres ponderiam, um a um, às diferentes ciências físico-naturais e às do espí rito. Deste ponto de vista, o homem é a própria natureza interiorizada, em-si e para-si, contendo num grau ou nível superior, física e metafísicamente falando, não apenas aquele universo de que se ocupam a biologia e as teorias da evolução mas um universo tomado consciente dele mesmo e da sua própria história. É este o papel que Quental, rejeitando uma leitura puramente mecanicista ou determinista da relação entre os referidos pla $\operatorname{nos}^{47}$ —na sequência do espiritualismo francês e da filosofia de Hart mann- mas não deixando, mesmo assim, de subscrever uma concepção monista e, em certa medida, panteísta, da mesma, atribui ao homem no cume ou no topo da hierarquia. ${ }^{48}$ É o homem assim compreendido, como vimos a propósito de Renouvier e do autor de A filosofia do inconsciente, que está em questão na apropriação e reinterpretação ocidental —através da dissociação metafísica, kantiano-shopenhaueriana, entre o mundo da ilusão ou das aparências e o do ser- da experiência búdica da redução

46 E von Hartmann, op. cit., cap. Ill, 29-51.

47 Veja-se A. de Quental, "A 'philosophia da natureza' dos naturalistas", in Prosas (Coimbra, Imprensa da Universidade 1931) vol. III, 22-51.

${ }^{48}$ Veja-se idem, Tendências gerais da filosofia na segunda metade do século XIX (Lisboa, Gulbenkian 1991) 99 e ss.. 
nirvânica ao Nada ou ao Não-Ser. Reflectindo sobre a natureza dessa experiência, afirma Quental num primeiro momento:

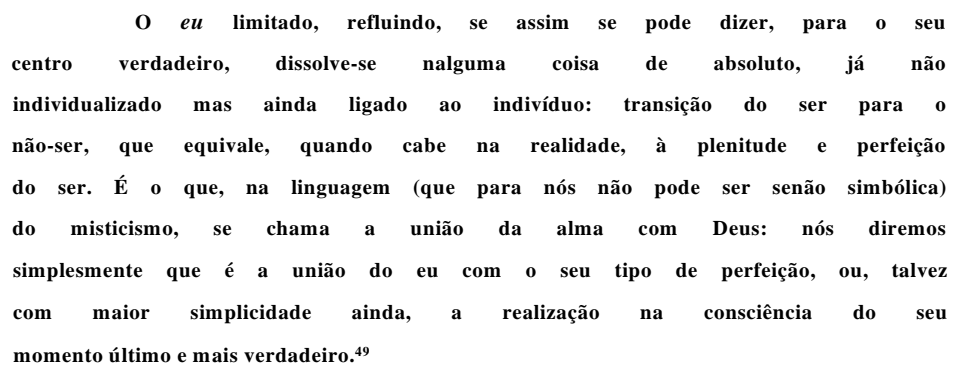

Muito se tem escrito sobre esta e outras passagens (em que se parece subscrever a versão de um budismo ortodoxo, corrente na época, sem nada lhe trazer de novo) relacionando-as com o suicídio do filósofo e a sua concepção da morte. E é assim que, na verdade, Oliveira Martins as interpretará. É esquecer que esse homem que está no vértice da hierarquia de planos ontológicos do real e acede, por aí, à unidade essencial do Todo na sua expressão mais pura ou sublime, logra alcançar também, para as Tendências, a realização dos valores fundamentais da apologética moral do cristianismo nas suas fundações: o bem, o amor, a justiça, a liber dade. ${ }^{50}$ Isso bastaria para mostrar que se trata de um budismo transfor mado e renovado, ou de um neo-budismo, em que, como Quental tinha prognosticado, se faz a síntese entre o Oriente, por um lado, e a metafísica e a religião ocidentais, por outro, no próprio seio destas últimas. Mas é também, como Coimbra mostrou no pequeno livro a que já aludimos e Fernando Catroga veio recentemente defender, ${ }^{51}$ ignorar a conecção nuclear entre o budismo anteriano e a problemática da filosofia da evolu ção. O homem, que preside à hierarquia, não é apenas o resultado da evolução do universo mas, outrossim, da sua involução: reapreendendo-o na sua essência, reapreende também a sua finalidade mais íntima ou essencial, à luz da qual o recolhimento na tranquilidade nirvânica, a fusão com o Todo e, por aí, a morte ela mesma, aparecem, nas conhecidas pala vras do poeta e filósofo, como “a manifestação física de uma necessidade

${ }^{49}$ Idem, ibidem, 106.

${ }^{50}$ Idem, ibidem, 106 e ss..

${ }^{51}$ Veja-se F. Catroga, Antero de Quental: história, socialismo e política (Lisboa, Editorial Notícias 2001) cap. IV, 74-105. 
metafísica". Outra coisa não virá a dizer Leonardo Coimbra do ponto de vista da sua própria filosofia.

Se Quental advogava à sua maneira, filosoficamente, um encontro entre o Ocidente e o Oriente, dando como justificação para o mesmo um pensamento que, na esteira do monismo e do panteísmo ale mão, concorda de maneira geral com aqueles mesmos aspectos que Renouvier e Hartmann atribuem às religiões orientais; se, deste ponto de vista e na sequência do segundo filósofo, subscreve um "budismo ocidentalizado" que está longe de se reduzir à sua versão ortodoxa; o facto é que nunca defendeu uma teoria geral das civilizações e, à luz desta, das religiões. É este o caso, pelo contrário, da historiografia de Oliveira Mar tins e, em particular, de um livro dedicado ao próprio poeta e filósofo açoriano (O helenismo $\boldsymbol{e}$ a civilização cristã), onde, em parte pelas mes mas razões que apoiariam o budismo de Antero, vamos encontrar uma clara rejeição das religiões orientais e, sobretudo, da possibilidade de um encontro civilizacional entre estas e o cristianismo. Subjacente a um tal des-encontro, contudo, está a reinterpretação de um cristianismo que se pretende renovado e em que podemos descortinar a influência do Oriente.

O budismo, na interpretação de Leonardo Coimbra, terá forne cido "alimento às atitudes metafísicas de Oliveira Martins."52 Não que este tenha pessoalmente defendido e subscrito o budismo, de facto, em qualquer das suas versões, mas porque, sob a forma da problemática da síntese entre o Ocidente e o Oriente e das "novas religiões" —aí incluindo a de Hartmann-, 53 ele estimulou o seu pensamento e, em particular, a sua filosofia da história. Uma vez dito isto, o facto é que o autor do livro acima referido e de $\boldsymbol{O}$ sistema dos mitos religiosos, ignora geralmente, se pusermos de lado o Egipto e a Pérsia, as religiões da orientais (o bramanismo e o budismo, em particular), sendo parco, se não mesmo algumas vezes críptico, na matéria. ${ }^{54}$ Isso não o impediu, entretanto, de protagoni zar uma marcada reacção contra a influência das mesmas e a tentativa da sua "unificação" com o cristianismo, a qual, para ele, não só era desneces sária como perniciosa. $\mathrm{Na}$ verdade, teria sido justamente uma tal influên cia que perverteu o espírito original do cristianismo resultante da síntese, até ao século IV depois de Cristo, entre o helenismo e o judaísmo, intro-

${ }^{52} \mathrm{Cf} .$, mais adiante, nota 67.

${ }^{53}$ Cf. O. Martins, O helenismo e a civilização cristã (Lisboa, Guimarães Editores $1985) 325$, nota 1.

^ Jdem, ibidem, 129-157; e idem, Sistema dos mitos religiosos (Lisboa, Guimarães Editores 1986) 155-172.

Faculdade de Letras | Universidade de Coimbra 
duzindo aí elementos espúrios e inaceitáveis, filosófica e moralmente falando, característicos das religiões orientais, que constituem, como ele diz, "a face oriental e histórica do Cristianismo, a que fulmina razão, natureza, liberdade e pensamento". ${ }^{55}$ A civilização cristã, quer dizer, a fusão entre judaísmo e cristianismo, nunca teria existido, segundo Martins, "se as raças bárbaras não estivessem junto das nações cultas da Antiguidade pedindo uma iniciação e um baptismo." ${ }^{56}$ É um tal cristianismo orientalizado e adulterado que, no seu entender, estará na base da intolerância do catolicismo da época, da apologia dos símbolos, dos dogmas e da autoridade da revelação em prejuízo da razão, do relevo dado a um monoteísmo abstracto, ao culto exterior e à ritual idade em detrimento da religiosidade interior, e, acima de tudo, do desprezo pela ciência e pelo espírito crítico. De onde, perante a profunda crise social, cultural e política da segunda metade do século XIX e, sobretudo, o conflito aparentemente insanável entre a religião, por um lado, e, por outro, a ciência e a filosofía, a sua apologia de um cristianismo renovado e do retomo às fundações deste anteriores à contaminação produzida pelo Oriente, apologia de que $\boldsymbol{O}$ helenismo $\boldsymbol{e}$ a civilização cristã é o testemunho historiográfico possível. De uma tal contaminação (e da concepção do mundo própria das religiões orientais) Martins dirá que:

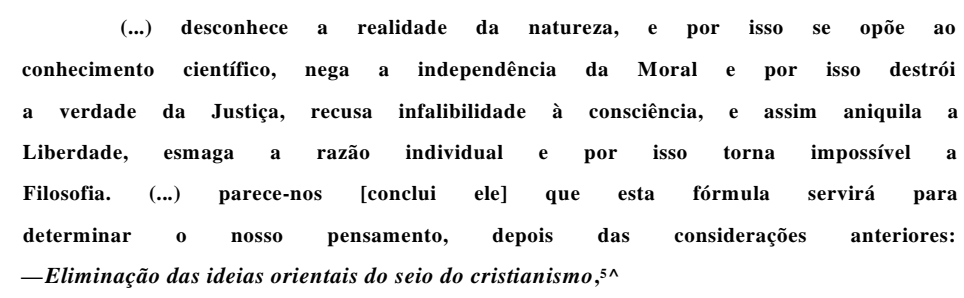

É possível perceber, por entre o arrazoado anti-oriental de Martins, que ele tinha em vista, em parte, alguns aspectos característicos do bramanismo e do budismo, na medida em que eram partilhados por outras religiões orientais, designadamente as da Pérsia antiga, como o panteísmo. ${ }^{58}$ Mas, o mais provável é que a sua abordagem crítica dos mesmos tenha sido feita através da filosofia alemã (a que estava traduzida em francês) e, em especial, dos trabalhos de Hartmann ou, como ele

55/í/em, O helenismo e a civilização cristã, 39.

^ldem, ibidem, 17.

$\wedge$ Idem, ibidem, 35.

58/í/ew, ibidem, 38.

Faculdade de Letras I Universidade de Coimbra 
escreve ironicamente a dada altura, da "embriaguês da irreligião".59 A crítica da "nova religião" e a defesa da renovação do cristianismo são desenvolvidas no quadro amplo de uma filosofia da história, de fundo hegeliano e proudhoniano, que passa por uma teoria a respeito da origem e desenvolvimento das civilizações, pelas relações entre a ciência e a filo sofia e, como se disse, pela reabilitação de um cristianismo originário que o Oriente teria, mais ou menos irremediavelmente, pervertido. $\mathrm{O}$ autor de O helenismo e a civilização cristã não ignora a importância da problemá tica do encontro das civilizações, pondo a "dialéctica das séries", de Proudhon, a justificar o encontro das raças e dos povos, como uma "con dição histórica necessária do progresso de humanização do Espírito". ${ }^{60}$ Mas um tal encontro terá como princípio motor, entretanto, "a superiori dade da civilização europeia", uma vez que esta, como ele diz, provém "dos melhores dotes das raças que vieram habitar o nosso continente."61 É deste ponto de vista que "Necessário é que à índia e à China, e a todas as civilizações orientais, temporariamente isoladas, chegue o momento de contacto que as faça entrar no sistema da história geral", ${ }^{62}$ embora não se saiba quando o facto virá a ocorrer. Seja como for, este encontro entre um Ocidente e um Oriente divorciados pressupõe a depuração do "carácter

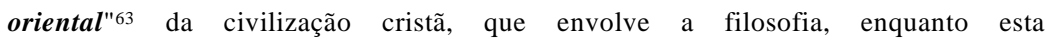
reduz a religião a um acontecimento puramente mundano e fenomenal (positivismo francês e monismo alemão), negando a necessária relação de transcendência-imanência de Deus com o homem e a natureza. ${ }^{64}$ Este é um ponto essencial do cristianismo renovado de Martins, que vai ao encontro, na matéria, do cristianismo de Quental e do de Leonardo Coim bra até certa altura, e em que, apesar de tudo, não deixam de se acolher algumas das propostas fundamentais das sínteses das "novas religiões", como as de $\boldsymbol{A}$ religião do futuro: um cristianismo sem revelação e, em última análise, sem criação, que não diviniza a natureza nem faz dela uma realidade auto-subsistente, que se funda na religiosidade interior de cada homem e, por meio dela, na valoração desinteressada do amor e da cari dade, e que respeita a sua inalienável individualidade e o exercício crítico da sua razão, sendo, nesta medida, o suporte fundamental da nossa civilização.

${ }^{59}$ Ibidem.

${ }^{60}$ Idem, ibidem, 13.

${ }^{61}$ Ibidem.

${ }^{62}$ Ibidem.

${ }^{65}$ Idem, ibidem, 39 (0 sublinhado é de 0. Martins).

${ }^{64}$ Idem, ibidem, 26 e sS..

Faculdade de Letras | Universidade de Coimbra 
Se é verdade, pois, que em Martins há um des-encontro entre o Ocidente e o Oriente, o mesmo — bem interpretado- não deixa de reflectir, no seu próprio âmbito, através da proposta de renovação e reo rientação do cristianismo, um encontro primeiro ou inicial, nunca admi tido ou confessado, com o espírito oriental das "novas religiões", que, pela sua parte, como vimos, Quental nunca enjeitou.

\section{Da interpretacãão do budismo, na sequência de Guyau, por parte de Leonardo Coimbra}

Da solução "budista ocidental" de Quental, como já se sugeriu, dirá Coimbra que ela coisifica ou substancializa a relação essencial entre o ser do homem e o Todo, ou o Ser ele mesmo (como diríamos hoje numa linguagem de embebência hedeggeriana e o próprio filósofo português virá a dizer a partir dos anos trinta), no sentido em que a redução nirvânica do poeta açoriano fica prisioneira do mesmo ilusionismo entre a aparência e o ser que tinha enredado Schopenhauer e o princípio dinamizador da progressão de grau para grau na hierarquia ontológica do real, da base até ao cume, não é verdadeiramente apreendido em toda a sua fecundidade criadora como, à partida, requeria o desenvolvimento da sua origem leibniziana. ${ }^{\wedge 5}$ Como mostra a crítica de Guyau, que Coimbra recupera, a Hartmann, a despeito das divergências deste com o autor de O mundo como vontade e como representação, a mesma dificuldade, que a sua ideia de Inconsciente só aparentemente encobre, poderia ser-lhe apontada. No complexo jogo de influências e conexões históricas que explicam uma filosofia como a das Tendências, e que $\boldsymbol{O}$ pensamento filosófico de Antero de Quental tão bem pôs em evidência, diríamos que o ilusionismo de Quental não é tanto o de A filosofia do inconsciente, o de Schopenhauer ou o de Kant, mas o de uma teoria espinozista da substância que, em contraste com o dinamismo herdado da monadologia de Leibniz, serve de pano de fundo à sua síntese ecléctica, pós-hegeliana e, sobretudo, pós-schellinguiana, das filosofias do tempo e, em particular, do espiritualismo francês.66 Seja como for, contra a interpretação de Oliveira Martins, se a redução nirvânica de Quental, que teria na morte (filosófica e pessoalmente falando) o seu maior expoente, fosse feita nos termos de um budismo ortodoxo, esvaziada de significação ética e, em última análise, de alcance metafísico ficaria a existência humana e a 6566

65 L. Coimbra, op. cit., 179 e ss..

66 Idem, ibidem, 66 e ss..

Faculdade de Letras i Universidade de Coimbra 


\section{Henrique Jales Ribeiro}

questão de saber qual é o seu destino. Se a morte fosse simplesmente a via de identificação do homem com o Todo ou da absorção no Nada budista em que é suposto este constituir, a ideia de que a vida e, com ela, a liberdade e a moral têm um sentido transcendente não possuiria mais verdadeiro interesse filosófico.

Em 1923, é verdade, no artigo "Sobre a saudade", Coimbra parece subscrever a aplicação a Quental, na esteira de Martins, da interpretação do budismo ortodoxo quando observa a dado passo:

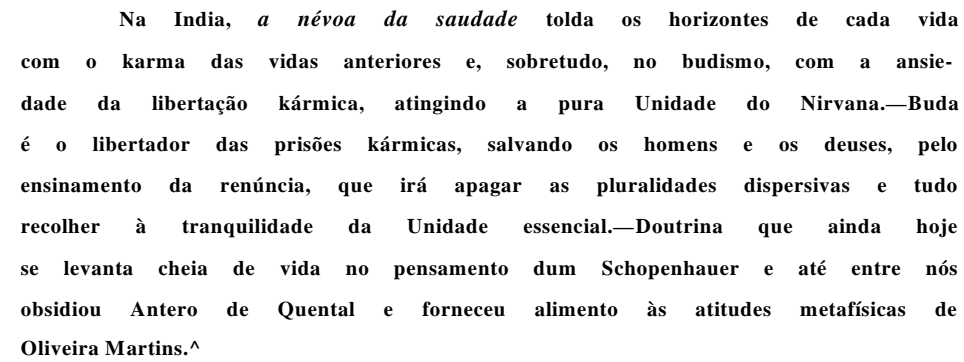

Mas, aqui, o ponto essencial, que afasta Coimbra dessa inter pretação e por intermédio do qual é feita uma interessante e surpreendente reabilitação do budismo ortodoxo -uma reabilitação criacionista--, é a ideia de saudade (cf. a expressão "névoa da saudade"), em que o filósofo projecta toda uma mundividência de raiz metafísica, que a sua filosofia, desde alguns trabalhos anteriores a $\boldsymbol{O}$ criacionismo, tinha explorado e desenvolvido de maneira persistente, —não exactamente a de "renúncia" ou a de "recolhimento" na "tranquilidade da Unidade essencial." Essa raiz é basicamente constituída por uma reinterpretação da ideia (a que temos vindo a aludir) de uma hierarquia de ciências que corresponderá a uma hierarquia de planos ou graus da natureza e do homem, - feita, de modo directo, na sequência do espiritualismo de Boutroux e da recepção da monadologia de Leibniz pelo criticismo de Renouvier, 67 68 e, mais remota mente, das sínteses filosóficas de Comte e de Hegel-, ${ }^{69}$ e que, desde as propriedades mais elementares do mundo à consciência livre (filosófica, $-151$.

67 In L. Coimbra, Dispersos, III, Filosofia e metafísica (Lisboa, Verbo 1988) 150-

68 É. Boutroux, La contingence des lois de la nature (Paris, Félix Alcan 1899); Ch. Renouvier, La nouvelle monadologie (Paris, Armand Colin 1899).

69 Cf. Henrique Ribeiro, "A 'síntese leibnizianá da teoria da ciência na segunda metade do século XIX: de Leonardo a Antero", in Revista filosófica de Coimbra (Coimbra 2001) 93 e ss..

\section{Faculdade de Letras | Universidade de Coimbra}


moral, artística e religiosa) do homem em sociedade e ao Espírito, cons tituirá o esqueleto ontológico fundamental da realidade. ${ }^{70}$ Para Coimbra, o princípio dinamizador da relação entre esses graus, que é uma esponta neidade criadora rompendo o determinismo da matéria e elevando-se grau a grau na hierarquia até coincidir com o próprio Espírito, só começa a manifestar-se em toda a sua plenitude com o aparecimento da consciên $\operatorname{cia}^{71}$ a qual, até esse plano, foi (como em $\boldsymbol{O}$ criacionismo se diz em termos neo-hegelianos) "construída" pela "dialéctica filosófica", ${ }^{72}$ e permaneceu, portanto, na linguagem de Hartmann, "in-consciente". Apli cando esta concepção, no quadro da filosofia da evolução, ao universo no seu conjunto, como ocorre no criacionismo e na sua filosofía da saudade, quer dizer, a um universo marcado pela entropia ou pela eventualidade do seu próprio desaparecimento, ${ }^{73}$ e não esquecendo que, à luz dessa aplica ção, o homem, estando no cume da hierarquia, está também no cume da evolução do universo, o paralelo entre esta e a redução nirvânica do budismo é evidente: dada essa relação consciência-inconsciência que apontámos, se, do ponto de vista cosmológico e do metafísico, a saudade passa fundamentalmente por apelar, através da memória cósmica incar nada pela memória pessoal de cada homem, para a história do universo —de um universo "in-consciente" que ele contém na sua própria essên cia--, ou para a sua própria história, desejando tomá-las presentes ou conscientes, porque nelas se esteve já essencialmente, de forma análoga, na perspectiva da redução nirvânica a saudade (a "névoa da saudade") consiste em desejar retomar à Unidade substancial e originária a que já se pertenceu de modo igualmente essencial, e a que, por isso mesmo e para todos os efeitos, se continua a pertencer.

Depois do que se disse e se sugeriu, poderemos nós falar de um neo-budismo de Coimbra? Observe-se, desde já, que em Coimbra encontramos geralmente a mesma versão de um budismo ortodoxo, para o qual a redução nirvânica é a redução ao Nada ou ao Não-Ser, que ocorre em Guyau. Condenando, como este, a funesta dissociação, de Kant e Schopenhauer, entre a aparência e o ser, ele foi conduzido a pensar que era um tal "ilusionismo" que estava metafísicamente na origem dessa redução, sem se aperceber, como Hartmann tinha mostrado, que ela não

$7^{0} \mathrm{Cf}$. L. Coimbra, o criacionismo (esboço de um sistema filosófico) (Porto, Renascença Portuguesa 1912) cap. I, 1-6.

71 Cf. idem, ibidem, 145 e ss., e, especialmente, 181.

72 Idem, ibidem, 1,3, 11, etc..

${ }^{73}$ Cf. ibidem, 8; e Dispersos, III, Filosofia e metafísica, 144 e ss.. 
era essencial para a definição do budismo. Não nos deve admirar, pois, que ele afirme sobre este, em 1922, no mesmo sentido em que o interpreta ao longo dos seus trabalhos:

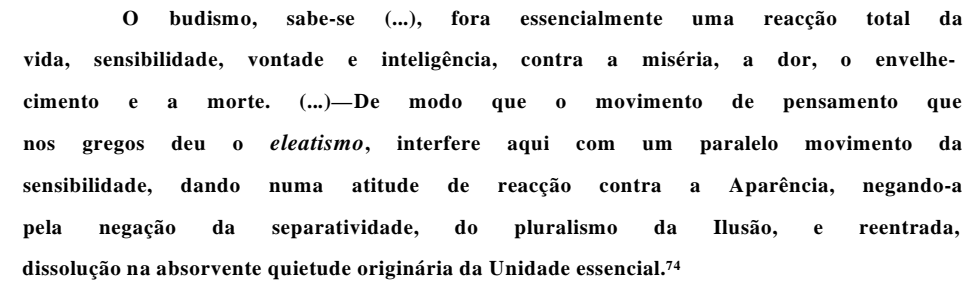

Contudo, como começámos por ver a respeito da sua interpre tação neo-budista da saudade, seria erróneo concluir que Coimbra rejeita simplesmente o budismo ou é seu adversário. Desde logo, porque a pro blemática histórico-filosófica de onde emerge o seu pensamento é justa mente aquela que temos vindo a analisar e que está na base da filosofia em geral de Hartmann a Renouvier e a Guyau. Não nos deve admirar, por isso, que, desde o início e até praticamente aos anos trinta (altura em que se adivinha a sua adesão ao catolicismo), ela gire em tomo dos mesmos temas fundamentais dessa filosofia: optimismo versus pessimismo na avaliação dos "tempos modernos", implicações das teorias da evolução para uma problemática filosófico-religiosa descristianizada, —em parti cular, a crítica de um naturalismo de tipo mecanicista e materialista (como em Quental), e a questão do teísmo versus panteísmo--, e, enqua drando todas estas matérias, o problema da relação entre o indivíduo e a Unidade essencial ou o Todo, ${ }^{75}$ que percorre quase todas as suas obras e cuja significação, como vimos mais acima, tem conecções claramente neo-budistas no pensamento da segunda metade do século XIX. De resto, se outras razões não houvesse, a influência decisiva de Guyau —em cuja filosofia perpassa esse tipo de conecções--, logo sobre os primeiros escritos de Coimbra, deveria levar-nos a repensar a sua rejeição do budismo, transformando-a num problema a esclarecer.

Retomemos a interpretação neo-budista da saudade, por parte de Coimbra, que se prende estreitamente com a da morte, a de Antero, a de cada um de nós e a de um universo ele mesmo perante o destino do seu eventual desaparecimento. Guyau tinha defendido, em A irreligião do

74 In L. Coimbra, Dispersos, IV, Filosofia e religião (Lisboa, Verbo 1991) 178.

75

Veja-se L. Coimbra, O pensamento criacionista (Porto, Renascença Portuguesa 1915) 188 ess..

\section{Faculdade de Letras | Universidade de Coimbra}


futuro, que a sua experiência-síntese do Todo ou da Unidade essencial não se reduz à vida humana, materialmente considerada, mas inclui a morte, a nossa e a do mundo ou dos mundos, e que, pois, contra as tenta ções especulativas a que se poderia ser conduzido pela redução nirvânica do budismo ortodoxo, a morte não deve ser encarada como um expediente que concretizaria, de algum modo, essa redução ou como seu instru mento. ${ }^{76}$ São ideias que $o$ autor tendo em mente não tanto Hartmann mas Schopenhauer e a história pessoal deste, sublinha com alguma insistên cia.77 A morte, a morte humana, é bem a absorção do Indivíduo pelo Todo, a sua fusão com a Unidade essencial, se por esta se entender não uma substância infinita abstracta mas a memória cósmica, universal, da essência de cada Indivíduo, quer dizer, do conjunto daquilo com que cada um de nós, através da experiência-síntese de aprofundamento, interiorização-expansão da sua vida ou da sua existência, contribuiu para o conhe cimento do Todo ou da Unidade essencial. ${ }^{78}$ Neste sentido, jamais se morre verdadeiramente, metafisicamente falando, ao contrário da inter pretação simplista que faz da redução nirvânica, no budismo ortodoxo, um sucedâneo ou um substituto da morte. Mas, de modo similar, como se disse, o universo, este mundo e outros quaisquer, segundo os dados mais actuais da ciência, na época, enfrenta o problema da extinção ou desapa recimento, quer dizer, o problema da morte ou do seu próprio destino. ${ }^{79}$ A filosofia do indivíduo e da vida, de Guyau, responde a este último desi derato fundamental com a resignação e a invocação derradeira do mistério cosmológico da nossa existência e da dos mundos, porque "a evolução deste globo [dos mundos] não parece ser ela mesma mais do que um aci dente" do Todo, ${ }^{80}$ macro-cosmologicamente considerado, ou do "grande Todo".81 Também nesta matéria as conexões budistas ou neo-budistas do pensamento do fdósofo francês são evidentes, porque o seu problema essencial é justamente o dessas doutrinas, a saber, como ele dirá pelas suas próprias palavras, o de "um ser que concebe a sua unidade funda mental com o Todo, que tomou consciência da sua eternidade", e que tem

76 Veja-se M. Guyau, op. cit., "L'immortalité dans le naturalisme monist", 430 e ss..

77 Idem, ibidem, 452 e ss.. Sobre a morte, na filosofia alemã da segunda metade do século XIX, veja-se M. Paul, Dieu est mort en Allemagne. Des lumières à Nietzsche (Paris, Payot 1994). E sobre a morte, no budismo, veja-se P. Arnold, "La réponse du boudhiome", in M. Marois et ali., La mort: Un terme ou un commencement (Paris, Fayard 1982) 391-409.

78 M

M. Guyau; L 'irréligion de l'avenir, 472 e ss.

^Idem ibidem, 446 e ss..

${ }^{80}$ Idem, ibidem, 441.

^ Idem, ibidem, 438. 
como destino a "dissolução [Nele] a partir do ponto em que esta tenha chegado à [sua ]existência". ${ }^{82}$

Coimbra, em $\boldsymbol{A}$ morte, subscreve inteiramente a teoria de Guyau e as implicações neo-budistas da mesma, que o artigo sobre a sau dade, à sua maneira, também evoca. Mas já desde os seus primeiros tex tos, no chamado "período pré-criacionista", ele tinha retomado a teoria da experiência-síntese do francês (para além do seu individualismo e vita lismo) como via fundamental da relação entre o Indivíduo e a Unidade essencial, ou o Todo, à luz da concepção da hierarquia das ciências e, correlativamente, dos planos ontológicos da natureza e do homem. ${ }^{83}$ E, também nele, o aprofundamento característico dessa experiência é conce bido como aperfeiçoamento, redução do transitório e fugaz ao que é permanente $\boldsymbol{e}$ essencial, numa perspectiva que vimos, a respeito de Guyau, constituir um budismo reinterpretado e transformado. O dado novo, em $\boldsymbol{A}$ morte, é o aparecimento, no âmbito da concepção hierárquica do ser, da ideia de memória, que constituiu, em Coimbra, uma condição básica para poder desenvolver uma filosofia da saudade, apenas esboçada em $\boldsymbol{O}$ criacionismo. A memória cósmica, de $\boldsymbol{A}$ irreligião do futuro, torna se agora "memória inventiva" no preciso sentido em que a memória de cada homem, no cume da hierarquia, o é, reapreendendo a espontaneidade criadora essencial em que consiste o dinamismo da relação entre esses planos e projectando-a do passado para o futuro, e, por aí, vencendo a morte, a morte pessoal e a morte dos mundos, quer dizer, fundindo-se finalmente com o Todo. ${ }^{84}$ Uma tal vitória, que recupera o tema do nir vana sob outras vestes, é coetânea da presença face à realidade do misté rio, que em Coimbra, muito mais do que em Guyau, tem feições claramente místicas e evocações neo-budistas não menos evidentes. ${ }^{85}$ O filósofo português insiste reiteradamente, ao longo dos seus escritos, que a Unidade a que assim se chega não é a Unidade abstracta e, por isso mesmo, vazia, do budismo ortodoxo mas a verdadeira e concreta Uni dade, ${ }^{86}$ de que a primeira não é se não aparência superficial ou, como ele

82 Idem, ibidem, 441.

83 Cf. $L$ Coimbra, "Aos poetas religiosos: uma monadologia (fragmento)", in Dispersos, I, Poesia portuguesa (Lisboa, Verbo 1984) 21-25.

84 Cf. idem, A morte (Porto, Renascença Portuguesa 1913) 72 e ss..

85 Cf. idem, ibidem, 112-114.

86 Cf. idem, ibidem, 70-72; idem, O pensamento criacionista, 217 e ss..; idem, A lutapela imortalidade (Porto, Renascença Portuguesa 1918) 94 e ss., 104 e ss., etc.; idem, O pensamento filosófico de Antero de Quental, 236 e ss.; e idem, A razão experimental: lógica e metafisica (Porto, Renascença Portuguesa 1923) 381 e ss.

\section{Faculdade de Letras | Universidade de Coimbra}


também sugere por vezes (particularmente em $\boldsymbol{A}$ alegria, $\boldsymbol{a}$ dor $\boldsymbol{e} \boldsymbol{a}$ graça) ${ }^{1}$ uma simples etapa a superar. Alumiando de uma outra perspec tiva o individualismo de Guyau, afirma, por isso, contra as pretensões de um tal budismo:

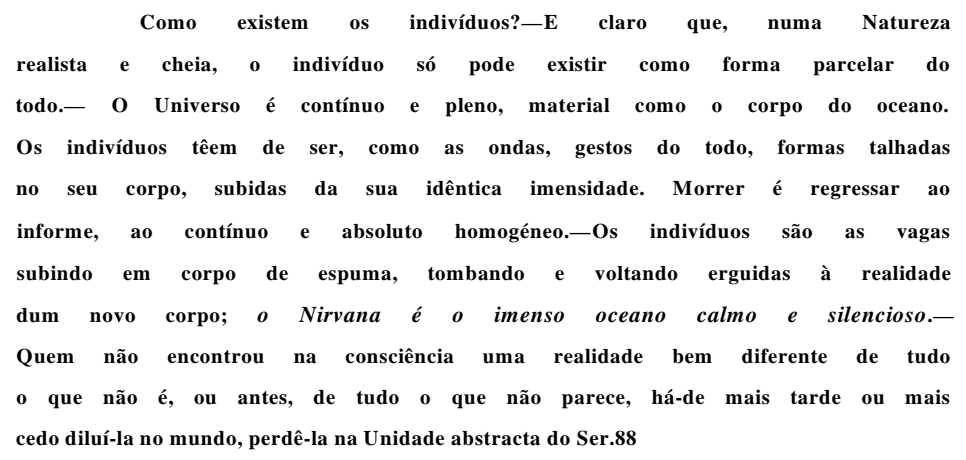

Trata-se, mais uma vez, de transcender a experiência simplista e limitada da redução nirvânica do budismo ortodoxo (feita no quadro da interpretação oficial deste durante grande parte do século XIX), de reorientá-la no seu verdadeiro sentido (o do individualismo e da filosofia da consciência e da vida de Guyau), alargando-a e aprofundando-a, e dandolhe, se assim se pode dizer, um novo alento.

\section{Epílogo}

\section{Dos fins da globalização filosófica, ou do re-encontro} possivel, hoje em dia, entre Ocidente e Oriente

Cedo, no panorama do pensamento filosófico europeu da segunda metade do século XIX, o desiderato de uma desejada globaliza ção chegará ao fim. A Primeira Grande Guerra, no próprio coração da Europa, dará um golpe mortal decisivo na ideia, claramente dividindo os diversos intervenientes na mesma, não apenas de um ponto de vista polí tico e militar mas também, se não de forma mais essencial, do social, cultural e filosófico. Daí as recorrentes tentativas de explicar a tragédia através de razões que pertenceriam à filosofia propriamente dita, fazendo da França do cartesianismo, do positivismo e do espiritualismo, contra

$8^{7} \quad$ L. Coimbra, A alegria, a dore a graça, (Porto, Renascença Portuguesa 1916) 191.

Idem, ibidem, 158, s. $\eta$..

Faculdade de Letras i Universidade de Coimbra 
uma Alemanha do pessimismo e do niilismo, do monismo e do pan teísmo, as partes fundamentais em disputa. Se a Europa, como os factos mostravam, não conseguia unir-se em torno de uma suposta racionalidade que a caracterizaría e que tinha sido a sua principal bandeira ao longo da história, obviamente não fazia mais sentido pensar num re-encontro entre Ocidente e Oriente que sintetizaria o que de melhor haveria nas duas civilizações. Mas outros factores concorreram, segundo alguns, para a destruição do sonho da globalização e, no caso, da eventualidade de um tal re-encontro no próprio seio de uma das partes fundamentais da Europa e do Ocidente de maneira geral: a evolução política e religiosa da Rússia -esse império europeu e asiático, "missionário da civilização euro peia", ${ }^{89}$ que, à sua maneira, sintetizava civilizacionalmente o encontro possível entre o budismo e o cristianismo, como tinha defendido Renouvier-, ${ }^{90}$ com a chegada ao poder do bolchevismo e de uma filosofia manifestamente materialista e ateia, veio comprovar à evidência a inanidade do desiderato da globalização. ${ }^{91}$ Também a própria evolução do pensamento europeu (logicismo, fenomenologia, hermenêutica, etc.), aí incluindo a de Coimbra em Portugal, se orientou em sentido bem dife rente, no que à filosofia da religião diz respeito, do da globalização. Seja como for, hoje em dia, face a uma concepção essencialmente tecnológica e imperialista da globalização, importa repensar essa primeira tentativa, fracassada, de mundialização filosófica, religiosa e cultural do século pas sado, aprendendo com ela num ponto verdadeiramente essencial: sob pena de esmagar a diversidade e a essencial relatividade das culturas, das sociedades e das religiões, $e$ da "'unidade de comunicações", de Renouvier, ficar apenas ao serviço, de forma leviana, deste ou daquele ideal político mais ou menos preponderante, a globalização há-de poder ter uma matriz filosófica, que passa, como na segunda metade do século $X I X$, por um sincretismo respeitador das diferenças fundamentais entre o Ocidente e oriente.

É este hoje em dia - humildemente profetizamos nós - o caminho de um re-encontro possível, à maneira hegeliana da aufhebung, entre as duas civilizações.

$\wedge$ 9 0 . Martins, op. cit., 350.

${ }^{99}$ Ch. Renouvier, Philosophie analytique de L'histoire, 749.

91 Veja-se, deste ponto de vista, L. Coimbra, A Rússia de hoje e o homem de sempre (Porto, Tavares Martins 1935).

Faculdade de Letras | Universidade de Coimbra 